\title{
Earth history and evolution of life in the high school curriculum of the state of São Paulo
}

\author{
C. P. Scott-Santos, J. M. Piranha
}

Graduate Program of Teaching and History of Earth Sciences, P0 Box 6152, 13083-855 Campinas, SP, Brazll

Reference Center in Earth System Science - CReCist, São Paulo State University -unesP

Rua Cristóvão Colombo, 2265 Bairro: Jardim Nazareth, CeP 15054-000, São José do Rio Preto - São Paulo - Brasil

E-MALL: CRISTIANE.SCOTT@GMAIL.COM,JOSEL.unESP@GMAIL.com

Abstract: Among the main obstacles to the literacy of the Earth System Sciences, the content organization in official curricula stands out. The knowledge of this science has been shown as fundamental for the formation of citizens who know how to use natural resources regarding environmental questions and life itself. Faced with such issues, the present study has done a documentary analysis of the Parâmetros Curriculares Nacionais para o Ensino Médio (PCNEM in Portuguese, or National Curriculum Parameters of Secondary Education) and of the Currículo do Estado de São Paulo (CESP in Portuguese, or School Curriculum of the State of São Paulo), with aim at suggesting effective teaching alternatives for citizens formation. Both the PCNEM and the CESP present contents in a fragmented way through traditional disciplines, such as has been the educational structure in Brazil for decades. The PCNEM suggest an interdisciplinary approach of these contents, while the CESP do not mention this type of approach, but relates skills to be developed to each type of content, and so presents interdisciplinary teaching as valuable. As an alternative to this pedagogical structure, it is proposed that the contents encompassed in the Earth System Science should be treated in an interdisciplinary context, allowing the integrated development of contents and contributing to the teacher's work.
Manuscript:

Received: Quadrennial Conference of the International Geoscience Education Organization Accepted: 05/06/2018

Citation: Scott-Santos C.P. \& Piranha J.M..2018. Earth history and evolution of life in the high school curriculum of the state of são paulo. Terræ Didatica, 14(3):296-303. URL: http://www.ige. unicamp.br/terraedidatica/.

Keywords:Earth Sciences teaching, Geological Time, Geoscience, high school, interdisciplinarity Thematic line: Education, Teaching of Geosciences and Teacher Training

\section{Introduction}

In recent years there has been a growing exploitation of natural resources, so that many of those resources are depleted and their misuse has had a negative impact on the natural dynamics of the Earth system (Mayer 1995). This fact stems from a lack awareness about the good functioning of the planet, sustainable exploitation and the conservation of natural resources. Such awareness should be provided to citizens during their school education (primary and secondary education) (Carneiro and Gonçalves 2010). It is understood that the curricular approach of primary and secondary education ${ }^{1}$ have not been suitable or satisfactory.

Dodick and Orion (2003) highlighted that the reception of incomplete scientific definitions

1 "Secondary education", in Brazil, is a term related to the last years of lower secondary education (about 2 or 3 years) and upper secondary education, commonly known as high school, which covers three years. In Brazil, this term refers strictly to high school years, while primary education encompasses all the prior nine school years (1st to 9th grade). by students of primary and secondary levels may lead to merely a partial understanding of the Earth System. LaDue and Clark (2012) pointed out conflicts between religious beliefs, as well as low significance and inadequacy of content for students as the main obstacles to literacy in Earth System Sciences, among other aspects. A holistic approach to issues in this area should be a priority in school education, with the important goal of enabling citizens to use sustainably the natural resources of the planet (Pedrinaci et al. 2013).

The Programme for International Student Assessment (PISA), which periodically evaluates the performance of students from all over the world, ranked Brazil in $63^{\text {rd }}$ among the 72 participating countries in the last evaluation, in 2015. Scientific knowledge of physics, life sciences and space sciences are assessed interdependently and interdisciplinarily (OECD 2016). The low performance of Brazilian students in this test indicates deficiencies of Brazilian school system in science education.

\begin{tabular}{c|c|c|c|c|c|}
\hline C Terrae Didat. & Campinas, SP & v.14 & n.3 & $296-303$ & jul./set. 2018 \\
\hline
\end{tabular}


Brazilian curricular proposals do not present a pedagogic structure that encourages interdisciplinary approaches in Earth System Sciences, once do not articulate the physical, chemical and biological phenomena that govern the dynamics of the planet's functioning (Toledo 2005). Countries as Italy, Spain and Portugal place the understanding of the Earth System on core of school curriculum, and present specific documents to guide teachers in preparation of interdisciplinary approaches in Earth Science, resulting in a holistic and deeper understanding about the Earth's evolutionary history and complexity (Souza 2015, Wysession et al. 2010, Bonito 2014).

In Brazil, education is guided by the Parâmetros Curriculares Nacionais do Ensino Médio- PCNEM (National Curriculum Parameters of Secondary Education), which is based on educational policies (Brasil 2018). In the state of São Paulo, the education is also guided by the School Curriculum of the State of São Paulo (Currículo do Estado de São Paulo-CESP) (São Paulo 2012a,b). The PCNEM includes strategies for the approaching of school contents, while the CESP presents itself as a guide to such contents.

Toledo (2005) analyzes and discusses approaches to Earth System Science content in the PCNEM. There is no single discipline related to the Earth Science in secondary education, and therefore the themes and concepts proposed by CESP are handled by different disciplines. Thus, the topics in Earth System should be studied in an interdisciplinary way for effective learning (Carneiro et al.2004, Toledo 2005, Martins \& Carneiro 2014).

In this article, we evaluate, discuss and reflect on the organization of contents related to Earth System Sciences through a documentary research (May 2004) of PCNEM and CESP, complementing the initial analysis made by Toledo (2005). Additionally, we propose alternatives to treat the problems in order to contribute effectively, bringing improvements to teaching of Natural Sciences.

\section{Methodology}

Our assessment of PCNEM and CESP was based on a documentary analysis, which consisted of critical readings, such as proposed by May (2004). From such readings, it was possible to study and make notes of conceptions and curricular guidelines present in the educational proposal of the State of São Paulo (Brazil) and also at the National level.

The present paper introduces emerging reflections and considerations from theoretical components study on which the research on progress is based.

Moreover, our reflection presents some alternative proposals that can help the effectiveness of interdisciplinarity in Natural Science education.

\section{Analysis and Discussion of the Official Documents Based on the Literature}

\subsection{Earth History and Life Evolution in National Curriculum Parameters of Secondary Education (Parâmetros Curriculares Nacionais para o Ensino Médio, PCNEM)}

The curricular components of PCNEM are organized in four parts: (I) Legal Bases (Brasil 2000a), (II) "Languages, Codes and Related Technologies" (Brasil 2000b; integration of Portuguese Language, Modern Foreign Language, Art and Physical Education), (III) "Natural Sciences, Mathematics and Related Technologies" (Brasil 2000c, integration of Biology, Chemistry, Physics and Mathematics) and (IV) "Human Sciences and Related Technologies" (Brasil 2000d, integration of History, Geography, Philosophy, Sociology and Psychology). The Ministry of Education (MEC) proposed such organization as an attempt to provide greater integration and interdisciplinary. In addition, MEC published the PCNEM+ (Brasil 2002a,b,c) to complement the PCNEM (Brasil 2000b,c,d)

Excerpts regarding PCNEM are presented below. As well as the discussion of critically aspects related to the Earth history and evolution of life for an effective learning.

PCNEM defines, in the part I (Brasil 2000a, Legal Bases), interdisciplinarity as a pedagogical practice that makes it possible to "articulate disciplines in an activity or study project, research and action" and consists in the assumption that:

[...] knowledge maintains a permanent dialogue with other knowledge, which may be of a questioning, confirming, completing, negating, amplifying nature, that illuminates undifferentiated aspects. (Brasil 2000a, p.75) 
Lück (2009) emphasized that the interdisciplinary integration process of curricular disciplines with current global issues, in the school environment, encompasses the integration and engagement of teachers.

Part III of PCNEM (Brasil 2000c, Natural Sciences, Mathematics and Related Technologies) highlights the issue raised by Lück (2009):

[...]Thus, the awareness of this interdisciplinary or transdisciplinary feature in a systemic view, not cancelling the necessarily disciplinary character of scientific knowledge but supplementing it, stimulates the perception of the interrelation between phenomena, essential for good part of the technologies, for the understanding of environmental issues and for the development of an articulated vision on the human being in its natural environment, as builder and shaper of this environment. (Brasil 2000c, p.9)

Yet within this context, PCNEM's proposal of interdisciplinarity contents can be checked in the following section:

Disciplinary learning in biology, whose setting - the biosphere - is an articulated whole, is inseparable from other sciences. The understanding itself of life emergence and evolution in its various forms of manifestation demands knowledge of the geological and environmental conditions that prevailed in the primitive planet. (Brasil 2000c, p.9)

Within the interdisciplinary perspective of Natural Sciences education, Chemistry can contribute to the holistic understanding of origin and evolution of life, changes in the subsystems of Earth, as well as their integration throughout the history of the Planet, such as exemplified by part III of PCNEM (Brasil 2000c):

$[\ldots]$ in the case of elemental sulfur: its distribution in the terrestrial globe follows a line that is determined by the volcanic regions, its production is based on its relatively low melting point and its chemical properties make it an essential material for the chemical industry. Despite their relevance, these properties are poorly remembered in the context of school education. (Brasil 2000c, p.30).

Physics, another science of nature, refers us to the organization of matter during the formation process of Earth, as well as its changes over time.
The formative and evolutionary processes of the Earth System can be better understood when the elements and physical processes are integrated into the contents that would be treated in the subjects of Geography, Biology, Chemistry and Mathematics. Following these aspects, PCNEM, part III, emphasize the necessity to define new dimensions in Physics teaching:

It is necessary to re-discuss which Physics to teach for enabling a better understanding of the world and an appropriate citizenship formation. [...] a Physics that discuss the origin of the universe and its evolution. (Brasil 2000c, p.23).

Another important discipline for interdisciplinary approach to the history of life on Earth is History, which contributes to understand the geological time. An interdisciplinary approach favors complex learning, such as proposed by Morin (2015), and can change the old anthropocentric conception on the nature (Esteves and Gonçalves 2015). The part IV of the PCNEM (Brasil 2000d, Human Sciences and Related Technologies) considers geological time as an assumption to understand the relationships between the human and nature, including the perception of planetary scale as well.

Geological time determines other ways of referring to the social time. By placing the age of the Earth in approximately 4.5 billion years, we can understand that the history of human societies corresponds to a small fraction of the time in the history of the planet. The comprehension of the geological time scale can place the role of humanity in the process of transformation of the nature, and dimension beyond the present time the limits and power of human actions (Brasil 2000c, p.24).

Despite highlighting how recent is the human origin and evolution regarding Earth's history, the suggestion of PCNEM (Part IV) is quite anthropomorphic, such as previously pointed by Esteves and Gonçalves (2015). For Zen (2001) and Dodick and Orion (2003) the study of geological time allows to understand the sequence of the geological and biological changes that occurred throughout the Earth's history, before the human origin. Anthropocentric educational approaches have been associated to negative attitudes, which are incompatible with the respect for the natural world (McShane 
2007, Quinn et al. 2015).

Although PCNEM emphasize the importance of the integration of different sciences to understand processes involved in the biosphere, the document does not indicate, for example, which geological conditions are being referenced. Consequently, it is teacher responsibility to integrate the subsystems geosphere, hydrosphere and atmosphere with the biosphere, and also to point the system which they that integrate (Wysession et al. 2010).

In addition, PCNEM still treat the curricular components within the same disciplines (biology, physics, chemistry, mathematics, etc.) such as prior to the last curricular reform. This shows that the organization of curricular parameters is still fragmented and teachers condition interdisciplinarity to the attempt of integration of the disciplines. Current curricular organization, knowledge of "Earth History" is addressed by the disciplines Geography and History, while the "Evolution of Life" should be treated by Biology. Toledo (2005) emphasizes that teaching the history of Earth should be approached as a whole and not as fragments, as it is organized by PCNEM. According to Morin (2015), compartmentalized approaches of contents, without knowledge integration and organization of broad ideas, results in deficient and incomplete learning, which he defines as "blind intelligence"

Toledo (2005) pointed that, in many cases, teachers may not have adequate training to address aspects of Earth System in an interdisciplinary way. According to Martins and Carneiro (2014), teacher training is currently undergoing a crisis due to numerous factors that hinder the formation of critical mass. Those factors range from inadequate course guidelines to the lack of prospects of students who enroll in licentiate or pedagogy undergraduate courses (Gatti 2014), especially licentiate courses of scientific degrees (Martins \& Carneiro 2014).

PCNEM+ (Natural Sciences, Mathematics and Related Technologies) (Brasil 2002a, p.19) states:

In spite of all the convergences, to form an articulated work program in one area, there are difficult obstacles that need to be transposed. First, it is necessary to find the real points of contact between disciplines of an area [...] to establish the bridges and the transit between the disciplines, which will not always interconnect in the same way all disciplines. Finally, one must identify, analyze and undo false similarities, translate different terms used for the same object, or distinguish the same terms used to identify different concepts. In short, it is necessary to understand and work on real or apparent convergences and divergences, establish and develop common themes and methods, and with this knowledge, prepare the discipline's and its set's work.

We believe that the tasks pointed by PCNEM + (Brasil 2002a) are hampered by problems with teacher training, such as those highlighted by Martins and Carneiro (2014) and Gatti (2014).

Another point addressed by PCNEM is the contextualization, which is defined in document as the action of "assuming that all knowledge involves a relation between subject and object" (Brasil 2000a, p.78). Interdisciplinarity and contextualization are portrayed in the PCNEM as complements of a diversified base that includes regional and local characteristics of school community (Brasil 1996, 2000a). The diversity of interpretations of contextualization on teaching process can offer the teachers multiple alternatives of didactic mediations in their complex task of planning and class organization (Kato \& Kawasaki 2011). In addition, contextualization of curricular components allows them to be placed in the students' reality, which is highly relevant in science teaching (Kato \& Kawasaki 2011). Considering those aspects, Earth System can be contextualized through different pedagogical practices, such as environmental studies, in which students visit rocky outcrops, paleontological sites, natural history museums, or through classroom practices or laboratories, where the student would make use of rocks and fossils and simulations of natural processes, among other activities that could be organized by teachers.

\subsection{Earth History and Evolution of Life in the Curriculum of the State of São Paulo (Currículo do Estado de São Paulo - CESP)}

The Secretary of Education of the State of São Paulo instituted a basic curriculum for state schools to approach contents (São Paulo 2012 a,b). Together with this document, the Caderno do Gestor (Manager's Notebook) was prepared, it guides the implementation of the Curriculum in schools, teacher's notebook and the student notebook, both with contents, methods and work strategies for classroom. These documents are 
organized by content to be addressed and skills to be developed in each of school grades.

The contents and skills that structure the Curriculum exist within those disciplines presented in PCNEM, which shows that the Curriculum's structure is still fragmented, as we mentioned. Thus, CESP aggregates the contents related to Earth System and the notion of geological time in the discipline Geography, while evolution of life is treated in Biology (São Paulo 2012a,b). In addition, Carneiro, Toledo and Almeida (2004) highlighted the lack of ordering of contents on Earth's history, and of interdisciplinary proposals, in CESP. The discipline of history includes contents only from prehistory (time between first stone tools and the invention of the writing system), with no mention of geological time as suggested by PCNEM.

Elliott (2015) discusses the use of Curriculum as an instrument of pedagogical orientation, since it may reduce the possibility of integrating different practices and limit pedagogical action in classroom. In this sense, Sicca et al. (2014) present a reflection made with groups of teachers of the basic education and emphasizes an increasing reduction in the curricular flexibility and consequent plastering of the pedagogical practice. In this way, work in the classroom suffers generalization and loses contextualization (Elliott 2015).

This content fragmentation could be mitigated by developing the skills proposed in the Curriculum, since they could guide the contextualization and interdisciplinarity of contents, as pointed by Lück (2009).

As pedagogical proposal, CESP presents that:

In fact, a curriculum referenced in competences assumes that the challenge of promoting the knowledge of each subject is articulated to the student's competences and skills. It is with these competences and skills that the student will be able to make critical reading of the world, questioning it to better understand it, inferring questions and sharing ideas, without, however, ignoring the complexity of our time. (São Paulo 2012a, p 12)

To our understanding, the reach of such competences could justify bringing together contents so that it could be holistically approached. Thus, the contents that would lead to the understanding of biological evolution could be integrated to those proposed for the understanding of the genealogical history of Earth, as well as the chemical physical processes involved.

One of CESP's aims related to Earth's biological history consists in "interpreting the history of life on Earth based on a chronological scale, highlighting main events (the emergence of life, of plants, of human kind, etc.)". However, this approach requires integration of geological time - which is partially handled in the disciplines Geography and Biology - with the main events of evolution treated in Biology, which also involve topics of Chemistry. We understand that such contents would lead to the understanding of biological evolution if integrated with those that promote the understanding of the Earth's geological history, and that normally explain chemical and physical processes involved.

\section{Final Remarks and Proposal}

The present documentary analysis shows that PCNEM and CESP differ in the organization of content, so that PCNEM places greater emphasis on interdisciplinarity than CESP, even though it brings contents in a compartmentalized way, such as the CESP. The curricular components "Earth's history" and "Evolution of Life", when integrated into secondary education and treated in an interdisciplinary way, enable the integration of knowledges between biological evolution and the planet's geological history. Cherif et al. (2001) highlighted that the study of the evolution of life on Earth is based on a set of ideas and various scientific evidences of a system characterized by biological and physical changes over time. An integrative approach of these contents could, then, contribute to the educational quality. As shown throughout this text, this disciplinary integration allows the students a better understanding of the relations between life (biosphere) and the environment contributors over time. Such knowledge leads to the understanding of human life on the planet, its implications and potentials, which contributes to the development of more conscious citizens. Besides, the integration of components could make for a more contextualized education, drawing upon regional and local aspects.

Pinheiro et al. (2007) emphasized that formation of citizens with the qualities addressed by CESP will not come true if the current teaching/ learning process remains the same. Castro (2016) rated the current secondary education system as failed and unable to achieve goals and meet the needs of students. The development of skills will 
happen only through very well structured teaching strategies, that consider the student's previous knowledge and that can be mediated by contextualizing the handled topics. So, aiming at offering a conceptual basis for the interdisciplinary teaching of History of Life on Earth, we propose the following strategies:

- Integrating the phylogenetic system to the geological time and the evolutionary processes;

- Building interdisciplinary approaches that enable the relationship between physical, chemical and biological processes involved in the transformation of the environment over the geological time, on one side, and the emergence and evolution of life on Earth on the other side;

- Relating the living biota and fossils to achieve a better understanding of the transformations and evolution of life, giving special attention to regional geological and paleontological components.

The first strategy we suggested would allow the student to build the notion of evolutionary process, by highlighting the history of biological evolution. Students could then understand the evolutionary relation between the human kind and other species, and also perceive the time of emergence of our species having the evolutionary history of our planet as a background. The second strategy would complement and deepen the knowledge covered by the first one, and also make room for contextualization of teaching, as we showed. Lastly, through the relation proposed in the third strategy the student would be presented to concepts and evidences for a holistic thinking about the Earth System's functioning, by understanding big and small events and processes (extinctions and emergences) and their implications regarding biodiversity. This learning proposal should offer the student a more effective understanding of essential curricular contents, as well as an enriched understanding of its role in the history of evolution of life on Earth. We believe that such learning would in fact enable the student (individual) to make choices and adopt postures in the future, featuring necessary and fundamental changes for the continuity of the individual's evolution on Earth.

Based on such proposals, we suggest that the curricular components should not be handled in inflexible disciplines, as they currently are, but in interdisciplinary and contextualized approaches, as suggested in the official documents (PCNEM and CESP), and affirmed by Lück (2009) and Morin (2015). In this way, it is evident that the integration of different disciplines (Biology, Chemistry, Physics, Geography and History) is necessary, in order to allow a better understanding of the contents.

Obviously, the complexity of integrating strategies should not be an obstacle to their own adoption, but an invitation to change the traditional way of teaching, mediated by the teacher. For such, it is necessary that teacher trainings incorporate the interdisciplinar approach, facilitating to teachers the understanding of processes that occur in the evolution of life and historical transformation of terrestrial environments. What we propose is not different from what is acknowledged as important in official documents. However, it requires the exiting of the "comfort zone" of such approaches based on strict scholarly disciplines. It also requires that teachers start to acknowledge and be aware of the teaching resources they have at their disposal, in order to provide knowledge contextualized with the student's reality. For Morin (2005) there is not a guide but a challenge, which incorporates a "motivation to think", reflect and approach the complexity from an interdisciplinary treatment of the contents of Nature Science.

The suggested changes look drastic when compared to current scholarly practices; however they are very useful, if we consider the contents treated in the classroom.

\section{Conclusion}

We can see from this analysis the need of a content integration that encompasses the Geological and Biological History of the Earth, since such contents allow the articulation of different disciplines. Reflections about PCNEM and the Currículo do Estado de São Paulo indicated some divergences between what each one recommend and the actual classroom work, especially as far as interdisciplinarity and contextualization of the contents are regarded. Although PCNEM presents the curricular components related to Earth History and Evolution of Life in five different disciplines - Biology, Physics, Chemistry, Geography and History - they acknowledge the importance of the disciplines articulation and present integrating proposals of some of these contents.

The Currículo do Estado de São Paulo presents 
History of Earth and Evolution of Life in the Geography and Biology disciplines, respectively. Despite relating skills to the learning of such contents, the way the contents are presented do not instruct teacher how to apply interdisciplinary approach. Those documents overall do not appear to recognize the role of contextualization for the development of the aforementioned skills.

It is important to stress, however, the importance of teacher's engagement. It is responsibility of this professional to integrate the contents and to apply the contextualized approach. Strategies proposed on this paper are meant to be used by teachers in their classroom practices.

An integrated portrayal of physicochemical and biological processes that regulate Earth's geological and biological evolution, as well as its historical variants inside the geological time, should not be limiting for the teacher's work. Instead, it should orient the practice of interdisciplinary and contextualizing holistic pedagogical practices.

\section{Acknowledgements}

We would like to thank our laboratory colleagues and anonymous reviewer who improved the quality of this manuscript. This study was funded by Capes.

\section{References}

Brasil. Lei de Diretrizes e Bases da Educação Nacional. Lei n. 9.394, de 20 de dezembro de 1996. Brasília, Brasil. URL: http://www.planalto.gov.br/ccivil_03/ leis/L9394.htm. Accessed 04.07.2018.

Brasil. Ministério da Educação. Secretaria de Educação Média e Tecnologia. 2018. Parâmetros Curriculares Nacionais para o Ensino Médio. Brasília: Min. Educação. Brasília: MEC/Semtec. 109p. URL: http:// portal.mec.gov.br/programa-saude-da-escola/195secretarias-112877938/seb-educacao-basica-2007048997/12598-publicacoes-sp-265002211. Accessed 04.07.2018.

Brasil. Ministério da Educação. Secretaria de Educação Média e Tecnologia. 2018. Parâmetros Curriculares Nacionais para o Ensino Médio. Brasília: Min. Educação. Brasília: MEC/Semtec. 109p. URL: http:// portal.mec.gov.br/seb/arquivos/pdf/blegais.pdf. Accessed 04.07.2018.

Brasil. Ministério da Educação. Secretaria de Educação Média e Tecnologia. 2000a. Parâmetros Curriculares Nacionais para o Ensino Médio. Parte I - Bases Legais. Brasília: Min. Educação. Brasília: MEC/ Semtec. 109p. URL: http://portal.mec.gov.br/seb/ arquivos/pdf/blegais.pdf. Accessed 04.07.2018.

Brasil. Ministério da Educação. Secretaria de Educação Média e Tecnologia. 2000b. Parâmetros Curriculares
Nacionais para o Ensino Médio. Parte II - Linguagens, Códigos e suas Tecnologias. Brasília: Min. Educação. Brasília: MEC/Semtec. 71p. URL: http:// portal.mec.gov.br/seb/arquivos/pdf/14_24.pdf. Accessed 04.07.2018.

Brasil. Ministério da Educação. Secretaria de Educação Média e Tecnologia. 2000c. Parâmetros Curriculares Nacionais para o Ensino Médio. Parte III - Ciências da Natureza, Matemática e suas Tecnologias. Brasília: Min. Educação. Brasília: MEC/Semtec. 58p. URL: http://portal.mec.gov.br/seb/arquivos/pdf/ciencian.pdf. Accessed 04.07.2018.

Brasil. Ministério da Educação. Secretaria de Educação Média e Tecnologia. 2000d. Parâmetros Curriculares Nacionais para o Ensino Médio. Parte IV - Ciências Humanas e suas Tecnologias. Brasília: Min. Educação. Brasília: MEC/Semtec. 75p. URL: http://portal. mec.gov.br/seb/arquivos/pdf/cienciah.pdf. Accessed 04.07.2018.

Brasil. Ministério da Educação. Secretaria de Educação Média e Tecnologica. 2002a. Orientações Educacionais Complementares aos Parâmetros Curriculares $\mathrm{Na}$ cionais. Ciências da Natureza, Matemática e suas Tecnologias. Brasília: Min. Educação. Brasília: MEC/ Semtec. 144p. URL: http://portal.mec.gov.br/ seb/arquivos/pdf/CienciasNatureza.pdf. Accessed 04.07.2018.

Brasil. Ministério da Educação. Secretaria de Educação Média e Tecnologica. 2002b. Orientações Educacionais Complementares aos Parâmetros Curriculares Nacionais. Ciências Humanas e suas Tecnologias. Brasília: Min. Educação. Brasília: MEC/Semtec. 104p. URL: http://portal.mec.gov.br/seb/arquivos/pdf/ CienciasHumanas.pdf. Accessed 04.07.2018.

Brasil. Ministério da Educação. Secretaria de Educação Média e Tecnologica. 2002c. Orientações Educacionais Complementares aos Parâmetros Curriculares $\mathrm{Na}$ cionais. Linguagens, Códigos e suas Tecnologias. Brasília: Min. Educação. Brasília: MEC/Semtec. 144p. URL: http://portal.mec.gov.br/seb/arquivos/pdf/ linguagens02.pdf. Accessed 04.07.2018.

Bonito, J. 2014. Reorganização das metas curriculares no ensino básico Português: o caso das Geosciências. Terrce Didática 10(3): 227-239

Carneiro C.D.R., Gonçalves P.W. 2010. Earth System Science for undergraduate Geology and Geography courses, Campinas, Brazil. Terrae, 7(1-2): 2940.

Carneiro C.D.R., Toledo M.C.M.de, Almeida F.F.M. 2004. Dez motivos para a inclusão de temas de geologia na educação básica. Rev. Bras. Geoc. 34(4):553-560. URL: http://ppegeo.igc.usp.br/ index.php/rbg/article/view/9787/9135. Accessed 04.07.2018.

Castro M.H.G. 2016. Entrevista: Maria Helena Guimarães: "Há um tédio generalizado entre os alunos do ensino médio". Texto de Beatriz Morrone e edição de Flávia Yuri Oshima. Época. URL: http://epoca.globo.com/ideias/noticia/2016/08/maria-helena-guimaraes-ha-um-tedio-generalizado-entre-os-alunos-do-ensino-medio.html. Accessed 04.07.2018.

Cherif A., Adams G., Loehr J. 2001. What on "Earth" Is Evolution? The Geological Perspective of Teaching Evolutionary Biology Effectively. The Am. Biol. Teach., 63(8):569-574 + 576-591 
Dodick J.T., Orion N. 2003. Introducing evolution to non-biology majors via the fóssil record: a case study from the Israeli high school system. The Am. Biol. Teach., 65:185-190.

Elliott J. 2015. Lesson y learning Study y la idea del docente como investigador. Rev Interuniversitaria de Formación de Profesorado, 84(29.3):29-46.

Esteves P.C.C., Gonçalves P. W. 2015. As representações de natureza presentes nos Parametros curriculares nacionais: Uma colaboração para a análise d conteúdos de Ciências Naturais. Perspectiva em Diálogo: Rev. de Educ. e Soc., 2(4):36-54.

Gatti B. 2014. Entrevista com Bernadete Gatti: "O que se percebe é que a questão da docência é sempre relegada como se fosse algo menor". Cadernos Cenpec - Nova série, 4(2):248-275.

Kato D.S., Kawasaki C.S. 2011. As concepções de contextualização do ensino em documentos curriculares oficiais e de professores de ciências. Ciências \& Educação, 17(1):35-50. URL: http://www.scielo.br/scielo.php?script=sci_artt ext\&pid $=$ S1516-73132011000100003. Accessed 04.07.2018.

LaDue N.D., Clark S.K. 2012. Educator perspectives on Earth System Science Literacy: Challenges and Priorities. J. of Geosc. Educ., 60:372-383. URL: https://www.tandfonline.com/doi/abs/10.5408/11253.1. Accessed 04.07.2018.

Lück H. 2009. Pedagogia interdisciplinar: fundamentos teóricos-metodológicos. 16. Petrópolis: Vozes. p. 71.

Martins J.R.S., Carneiro C.D.R. 2014. Contribuições do ensino de Geociências à formação de uma massa crítica de professores e investigadores. Terrce Didatica, 10(3):368-377. URL: https://www.ige. unicamp.br/terraedidatica/V10_3/PDF/TDv10-3130.pdf. Accessed 04.07.2018.

May T. 2004. Pesquisa documental: escavações e evidências. In: May, T. Pesquisa social: questões, métodos e processos. 3. Ed. Porto Algere: Artmed. p. 205230.

Mayer J.M. 1995. Using the Earth System for Integrating the Science Curriculum. Southampton, Sci. Edu., 79(4):375-391.URL: http://onlinelibrary. wiley.com/doi/10.1002/sce.3730790403/pdf. Accessed 04.07.2018.

McShane K. 2007. Anthropocentrism vs. Nonanthropocentrism: Why Should We Care?" Envirom. Values, 16(2):169-186.

Morin E. 2015. Introdução ao pensamento complexo. 5. Ed. Porto Alegre: Sulina. 120p.

OECD. Organisation for Economic Co-operation and Development. 2016. PISA 2015 Results in Focus.V. 5
URL: http://www.oecd.org/pisa/pisa-2015-resultsin-focus.pdf. Accessed 8.08.2017.

Pedrinaci E., Alcalde S., Alfaro P. et al. 2013. Alfabetización em Ciencias de La Tierra. Earth Science Literacy. Enseñanza de las Ciências de La Tierra, 21(2):117-129.

Pinheiro N.A.M, Silveira R.M.C.F, Bazzo W.A. 2007. Ciências, tecnologia e sociedade: a relevância do enfoque CTS para o contexto do Ensino Médio. Ciências \& Educação, 13(1):71-84.

Qinn F, Castéra J, Clément P. 2016. Teachers' conceptions of the environment: anthropocentrism, non-anthropocentrism, antropomorphism and the place of nature. Environ. Educ. Res., 22 (6): 893917.

São Paulo (Estado). Secretaria da Educação. 2012a. Currículo do Estado de São Paulo: Ciências da Natureza e suas tecnologias. 1. ed. São Paulo: SE. 152 p. URL: http://www.educacao.sp.gov.br/a2sitebox/arquivos/documentos/780.pdf. Accessed 04.07.2018.

São Paulo (Estado). Secretaria da Educação. 2012b. Currículo do Estado de São Paulo: Ciências Humanas e suas Tecnologias. 1. ed. São Paulo: SE. 152 p. URL: http://www.educacao.sp.gov.br/a2sitebox/arquivos/documentos/781.pdf. Accessed 04.07.2018.

Sicca N.A.L., Goncalves P.W., Fernandes M.C.S.G. et al. 2014. Interfaces currículo do ensino médio e Geociências: 10 anos de reflexões de grupo de pesquisa colaborativa. Terre Didatica, 10:357-367. URL: https:/www.ige.unicamp.br/terraedidatica/V10_3/ PDF/TDv10-3-128.pdf. Accessed 04.07.2018.

Souza E.R. de. 2015. O Potencial das Ilustrações Geoscientífica textos didáticos: representação da dinâmica interna da Terra. Campinas. Inst. Geoc. UNICAMP. 469 $\mathrm{p}$ (PhD Thesis).

Toledo M.C.M. de. 2005. Geociências no Ensino Médio Brasileiro. Análise dos Parâmetros Curriculares Nacionais. Geol. USP, 3:31-44. URL: http:// www.revistas.usp.br/gusppe/article/view/45368. Accessed 04.07.2018.

Wysession M., Taber J., Budd D. A., Campbell K., Conklin M., LaDue N., Lewis G., Raynolds R., Ridky R., Ross R., Tewksbury B.,Tuddenham P. (org.). 2010. Earth Science Literacy: The big Ideas and Supporting Concepts of Earth Science. National Science Foundation. URL: http://www.earthscienceliteracy.org/es_literacy_6may10_.pdf. Accessed 8.02.2017.

Zen, E. 2001. What is deep time and Why should anyone care? J. of Geosc. Educ., 49(1):5-9. URL: https://serc.carleton.edu/files/nagt/jge/abstracts/zenv49p5.pdf. Accessed 10.03.2017. 